Nowoczesne Systemy Zarządzania

Zeszyt 12 (2017), nr 4 (październik-grudzień)

ISSN 1896-9380, s. 147-155

Modern Management Systems

Volume 12 (2017), No. 4 (October-December)

ISSN 1896-9380, pp. 147-155
Instytut Organizacji i Zarządzania

Wydział Cybernetyki

Wojskowa Akademia Techniczna

w Warszawie

Institute of Organization and Management

Faculty of Cybernetics

Military University of Technology

\title{
Środki publiczne oraz sponsoring jako sposoby finansowania sportu
}

\section{Public funds and sponsoring as a means of financing sport}

\author{
Oleh Ożarowski \\ Doktorant Uniwersytetu Ekonomicznego w Krakowie
}

\begin{abstract}
Abstrakt. Tematem pracy są pytania dotyczące finansowania sportu osób pełnosprawnych i osób z niepełnosprawnościami. Praca dotyka podstawowych założeń ekonomii dotyczących udziału państwa w sferze gospodarczej, prezentując obszary, w których udział ten jest konieczny. Przedstawione zostają dobra i usługi publiczne, a także sport jako jedna z kategorii usług publicznych.

Słowa kluczowe: finansowanie, niepełnosprawność, nierówności, sport.

Abstract: The subject of this work are questions about financing the sport of non-disabled people and financing the sport of people with disabilities. The work touches the basic assumptions of the economy regarding the state's participation in the economic sphere, presenting areas in which this participation is necessary. It presents public goods and services, as well as sport as one of the categories of public services. Keywords: financing, disability, inequality, sport.
\end{abstract}

\section{Wstęp}

Sport, dzięki swoim wspaniałym ideom, takim jak chociażby równość szans, oraz zasadom, jak fair play, rozwijał się we wszystkich częściach świata. Przez wieki powstawały nowe dyscypliny, nowe metody, reguły czy taktyki. Niezmienne było również to, że zawsze wiązał się z rywalizacją, która jest naturalna dla człowieka. To właśnie dzięki tej ludzkiej naturze sport jest dziś silnie skomercjalizowany i posiada ogromne znaczenie społeczno-ekonomiczne na całym świecie. Jedną z idei sportu jest równy dostęp do niego. Pomimo tego, że istnieją dyscypliny, które wymagają olbrzymich nakładów finansowych, w najprostszej formie sport powinien być 
dostępny dla każdego. Czymś innym jest sport zawodowy, który zdecydowanie różni się od podstawowych jego form. Obecnie stanowi ważną gałąź gospodarki, przez którą przepływają ogromne kwoty pieniędzy. Dostęp do sportu zawodowego nie jest jednak równy dla wszystkich, dlatego rolą państwa jest niwelowanie tych nierówności.

\section{Wydatki budżetowe $i$ sponsoring $w$ polskim sporcie}

Jak wcześniej wspomniano, sport jest współcześnie procesem bardzo skomercjalizowanym i sprofesjonalizowanym. Dlatego warto przedstawić, na czym polegają te dwa zjawiska oraz jak wygląda komercjalizacja i profesjonalizacja w sporcie. Pojęcie komercjalizacji wywodzi się z języka łacińskiego i oznacza postępowanie, które polega na liczeniu się wyłącznie z tym, co przynosi zysk. Słownik języka polskiego podaje zaś informację, że słowo to może wywodzić się z języka francuskiego i oznaczać oparcie działalności na zasadach handlowych i dostosowanie do zasad gospodarki rynkowej. Komercjalizacja to opieranie się na zasadach komercyjnych, co ma uczynić działalność opłacalną, przynoszącą dochód. Pomimo tego że współcześnie wiele innych sfer życia wiąże się ze specjalizacją i homogenicznością grup społecznych, to właśnie sport rozprzestrzenia swój zasięg wśród zróżnicowanych grup, a jego znaczenie staje się coraz większe. Mówienie o komercjalizacji sportu oznacza postrzeganie go jako towaru, który posiada określoną wartość rynkową.

Sport jako produkt coraz bardziej się udoskonala i umiędzynarodawia. W erze globalizacji, a więc postępującego, przyspieszonego procesu wzrostu powiązań i współzależności w gospodarce światowej, również sport stanął przed wyzwaniem i szansą działalności w sferze globalnej.

Organizacje oraz wydarzenia sportowe mogą być finansowane zarówno ze środków pochodzących z budżetu państwa, jednostek samorządu terytorialnego, jak i od prywatnych inwestorów i sponsorów. Warto zaznaczyć, że zarówno organizacje i wydarzenia o charakterze w pełni państwowym, jak i całkowicie prywatnym oraz organizacje sektora trzeciego korzystać mogą $\mathrm{w}$ różnym stopniu $\mathrm{z}$ obu możliwości finansowania. Celem tego podrozdziału będzie przedstawienie tych dwóch możliwości.

Skarb państwa finansuje te elementy świata sportu, które działają w skali krajowej, pozostawiając dalsze działania samorządowi terytorialnemu i wyłącznie go wspierając. Leszek Patrzałek uważa takie zachowanie za rozsądne, ponieważ przejmowanie znacznej części zadań publicznych przez samorządy wynika z nieracjonalności sektora publicznego w państwie silnie scentralizowanym, ze względu na trudną ocenę rzeczywistych potrzeb mieszkańców i dostosowanie do nich alokacji dostępnych środków. W myśl Ustawy o sporcie z 2010 roku państwo wpiera sport poprzez:

- dofinansowanie uprawiania lub organizowania sportu oraz jego promocję - minister właściwy ds. kultury fizycznej; 
- wspieranie, także finansowo, rozwoju sportu w środowisku szkolnym i akademickim - minister właściwy ds. oświaty i wychowania;

- wspieranie, także finansowo, rozwoju sportu w jednostkach podległych minister obrony narodowej i minister właściwy ds. wewnętrznych;

- finansowanie kosztów opieki medycznej nad zawodnikami kadry narodowej w sportach olimpijskich i paraolimpijskich z budżetu państwa - minister właściwy ds. zdrowia;

- finansowanie kosztów wydania zaświadczenia lekarskiego, w tym wykonania niezbędnych badań, zawodnikom poniżej 23. roku życia, którzy nie otrzymują wynagrodzenia w związku $\mathrm{z}$ uprawianiem sportu - minister właściwy ds. zdrowia,

- przyznawanie członkowi kadry narodowej stypendium sportowego za osiągnięte wyniki - minister właściwy ds. kultury fizycznej;

- przyznanie świadczeń dla medalistów olimpijskich i paraolimpijskich minister właściwy ds. kultury fizycznej.

Współcześnie sponsoring jest elementem wielu dziedzin życia, m.in. właśnie sportu. Jako sponsoring sportu możemy rozumieć działania firm, które obejmują finansowanie oraz wpieranie usługami lub dobrami rzeczowymi sportowców, organizacje sportowe lub imprezy sportowe w zamian za świadczenia podmiotów sponsorowanych. Świadczenia te mają charakter promocyjny i komunikacyjny dla sponsora. W innym rozumieniu sponsoring sportu to zarządzanie wszelkimi działaniami polegającymi na przekazywaniu różnych środków na rzecz organizacji sportu w celu osiągnięcia efektu biznesowego i promocyjnego. Marek Datko wyróżnia trzy etapy ewolucji marketingu sportowego. Pierwsza faza to mecenat i wpieranie. Rozpoczęła się ona, gdy sponsoring zaczął być zauważalny jako zjawisko, a więc w latach ubiegłego wieku. Dlatego dziś nadal jest czasami mylony z charytatywnością, choć jak wcześniej wspomniano, są to różne zjawiska. Druga faza wyróżniona przez M. Datko zawiera sponsorowanie w zamian za określone korzyści. Ten rodzaj sponsoringu ma jeszcze dziś duże znaczenie. Jego przykładem może być umieszczanie logo na stroju sportowym. Ostatni etap ewolucji sponsoringu to nabywanie praw do wykorzystania faktu sponsorowania przedsięwzięcia do własnych działań promocyjnych i reklamowych. Faza ta obejmuje już nie tylko zainwestowanie funduszy w bezpośredni sponsoring, lecz także przeznaczenie środków na rozpowszechnienie tej informacji. Warto zaznaczyć, że przez przedsięwzięcie rozumiemy zarówno indywidualnych sportowców, kluby sportowe, organizacje sportowe, jak i różnego rodzaju wydarzenia związane ze sportem (Patrzałek, 2004, s. 9-10).

Bardziej rozwiniętą formą jest zaangażowanie jednokierunkowe, inaczej zwane skoncentrowanym. Odbywa się ono na większą skalę i prowadzone jest przez dłuższy okres, skupiając się na konkretnej dziedzinie. Najbardziej aktywne jest zaangażowanie wielokierunkowe, które polega na sponsorowaniu różnych dziedzin. Sponsoring pełni w tym wypadku najważniejszą pozycję w polityce promocyjnej firmy, a co za 
tym idzie, na sponsoring przeznaczana jest znaczna część wydatków. Ze względu na sponsorowane podmioty możemy mówić o wpieraniu osobowym, instytucjonalnym oraz projektowym. Wspieranie osobowe polega na sponsoringu konkretnej osoby lub ewentualnie jednego zespołu/drużyny. Szerszy jest natomiast wymiar instytucjonalny, który polega na sponsorowaniu całej organizacji. Odmienny charakter ma sponsorowanie projektowe, polegające na sponsorowaniu przedsięwzięcia w fazie projektowania. Sponsoring może mieć ponadto różny zasięg oddziaływania. W tym wypadku zależy od samego sponsora, na jakiej promocji mu zależy - czy będzie to zasięg wyłącznie lokalny, czy też na skalę międzynarodową.

$\mathrm{Z}$ zasięgiem sponsorowania bezpośrednio połączony jest cel, jaki zamierza osiągnąć sponsor. Sporek wyróżnia dwa rodzaje sponsoringu w tej dziedzinie, a mianowicie sponsoring, którego celem jest rozgłos, oraz taki, którego celem jest stworzenie wizerunku. Zadaniem pierwszego jest poinformowanie opinii publicznej o firmie sponsora, a także spopularyzowanie marki, natomiast drugi rodzaj polega na budowaniu wizerunku i obrazu marki sponsora poprzez kojarzenie go ze sponsorowanym przedsięwzięciem. Sposób ujawniania opinii publicznej nazwy sponsora może być podzielony na imienny oraz emblematowy. Pod pojęciem sposobu imiennego możemy rozumieć pojawianie się nazwy w określeniach wskazujących na tytuł sportowego przedsięwzięcia bądź też obok jego nazwy. Za emblematowy uznać możemy taki sposób ujawniania nazwy sponsora, gdzie sponsor otrzymuje prawa do posługiwania się emblematem, herbem, logo podmiotu sponsorowanego w trakcie swoich działań promocyjnych. Ze względu zaś na liczbę sponsorów, którzy angażują się w sponsorowanie danego przedsięwzięcia, możemy wyróżnić sponsoring wyłączny, co-sponsoring oraz sponsoring dominujący. Pod pierwszym pojęciem kryje się prosta zasada, że jeden sponsor wpiera przedsięwzięcie i czerpie korzyści ze sponsoringu. Jest to metoda bardzo kosztowna, ale przynosząca największe rezultaty. Co-sponsoring polega na współsponsorowaniu przedsięwzięcia przez kilka firm. Ważne jest, aby sponsorzy nie działali na tych samych rynkach, przez co mogliby ze sobą konkurować. Dominujący sponsoring opiera się na podobnych zasadach co co-sponsoring, jednak jeden ze sponsorów ponosi znacząco większe koszty, ale też uzyskuje największe świadczenia ${ }^{87}$. Ten właśnie rodzaj sponsoringu jest najpopularniejszy w świecie sportu, gdzie mamy do czynienia z olbrzymią liczbą sponsorów, jednak każdy chce się w jakiś sposób wyróżniać na ich tle. Jednym z efektów takich działań jest chociażby wykupywanie nazw obiektów sportowych bądź nawet nazw drużyn - już nie tylko dodawanie elementu w postaci nazwy sponsora, lecz także całkowita zmiana nazwy na jego potrzeby. Zachowania takie często poddawane są dyskusji co do słuszności i etyczności w stosunku do ugruntowanej wcześniej tradycji, jednakże są efektem rozwijającego się rynku sportowego i ciężko będzie je zatrzymać. 
Kontynuując temat zalet wynikających ze sponsoringu, rozważyć można różne płaszczyzny, na jakie oddziałuje sponsor na rynku sportowym. Sponsoring, zdaniem J. Krawulskiego, odbywa się na czterech płaszczyznach:

- image firmy,

- firma,

- klient,

- społeczność lokalna.

Pod pojęciem image’u firmy rozumieć możemy wzrost renomy i prestiżu, kształtowanie wizerunku firmy oraz możliwość wprowadzenia produktu na rynek pod pretekstem innego wydarzenia sportowego. Jeśli chodzi o samą firmę, to celem sponsoringu może być podnoszenie lojalności i motywacji wśród jej pracowników, ale też kwestie prowadzące do czystego zysku, takie jak: wzrost wielkości sprzedaży, wzmocnienie relacji z partnerami biznesowymi oraz osiąganie zwielokrotnionych celów. W odniesieniu do klienta sponsor może dotrzeć do wyselekcjonowanej grupy, a także kształtować postawy konsumpcyjne. Ponadto sponsoring w sporcie pozwala na podkreślenie społecznej odpowiedzialności biznesu w oczach opinii publicznej oraz powiązanie określonego stylu życia z produktem.

Jak wskazano w tym podrozdziale, sport może być finansowany z dwóch głównych źródeł. Aby otrzymywać odpowiednie środki publiczne, należy spełniać określone zasady wyznaczone przez przepisy prawa. Wkład państwa w finansowanie sportu nie jest jednak tak ogromny jak sponsoring prywatnych jednostek.

\section{Nieprawidłowości we wspieraniu sportu z budżetu państwa i jednostek samorządu terytorialnego}

Pomimo powstania Ustawy o sporcie z dnia 25 czerwca 2010 r., która miała jasno uregulować przepisy dotyczące finansowania polskiego sportu, nadal zauważyć możemy liczne nieprawidłowości w funkcjonowaniu tej sfery. W tym punkcie przedstawione będą problemy związane $\mathrm{z}$ finansowaniem przez państwo, a następnie zanalizowane zostaną raporty Najwyższej Izby Kontroli dotyczące wspierania polskiego sportu ze strony państwa i jednostek samorządu terytorialnego.

Jak pokazał rozdział pierwszy, kwestia ingerencji państwa w różne sfery życia człowieka, w tym sport, nie jest oczywista i stanowi spór wśród ekonomistów. Aby dokonać analizy nieprawidłowości i problemów, jakie mogą wynikać z finansowania sportu przez państwo, należy przyjąć, że finansowe wspieranie sportu jest słuszne, lecz zastanowić się też, jakie niesie ze sobą zagrożenia.

Pierwszym problemem, jaki wiąże się z finansowaniem sportu z budżetu państwa bądź jednostek samorządu terytorialnego, jest sprawiedliwa alokacja funduszy. W ekonomii stosowane jest w tej sytuacji pojęcie problemy wyboru. Joseph Stiglitz zauważa, że często, aby dokonać odpowiedniego podziału, wchodzimy w konflikt 
pomiędzy efektywnością a sprawiedliwością społeczną. Podobny problem dotyczy finansowego wspierania sportu. Po pierwsze, władze powinny zwrócić uwagę, czy istnieje społeczna potrzeba wspierania sportu oraz w jakim wymiarze - tak aby nie zaburzać proporcji pomiędzy innymi istotnymi dla mieszkańców potrzebami. Sport w skali rekreacyjnej bądź też amatorskiej z ekonomicznego punktu widzenia jest przedsięwzięciem nieefektywnym, gdyż poza pozytywnymi, społecznymi efektami zewnętrznymi, o których była mowa w rozdziale pierwszym, nie przynosi wymiernych zysków - wręcz przeciwnie, generuje straty. Co więcej, często sytuacja taka dotyczy również klubów profesjonalnych, w które władze inwestują często nie dla zysków, lecz licząc się ze stratami.

Pomimo tego, często te inwestycje uważa się za sprawiedliwe. Problemem natomiast może być samo finansowanie wewnątrz sportu, tzn. ze względu na wielkość funduszy rozdzielanych pomiędzy kluby, dyscypliny i samych sportowców. W kwestii rozdzielania funduszy wewnątrz sportu patologią jest często zaangażowanie środków według sympatii i własnego uznania decydentów, bez konsultacji ze społeczeństwem, a nawet bez jakiegokolwiek uznania woli społecznej. Nie ulega wątpliwości, że największe fundusze przeznaczane są na piłkę nożną, która jest sportem najbardziej powszechnym. Ze względu na tę kwestię często pomijane są kluby, które prowadzą zajęcia z mniej popularnych dziedzin. Aby zachować odpowiednie proporcje pomiędzy użytecznością a sprawiedliwością, należy posłużyć się społeczną krzywą obojętności, która obrazuje społeczną ocenę użyteczności finansowania jednego przedsięwzięcia i drugiego. Zastosować należy również zasadę Pareto, mówiącą o tym, że trzeba tak alokować zasoby, aby poprawić sytuację jednostki (w tym przypadku grupy/klubu sportowego) bez pogarszania sytuacji innej jednostki (w tym wypadku społeczeństwa).

Pewne niejasne lub ogólne przepisy, zawarte w Ustawie o sporcie, sprzyjają korupcji, czyli zjawisku nadużycia pełnionej przez siebie funkcji w celu uzyskania prywatnych korzyści. Korupcja w polskim sporcie kojarzona jest najczęściej z ustawianiem meczów czy zawodów sportowych. Jest to jednak wyłącznie element zjawiska, które może mieć swój początek już na wyższym szczeblu, czyli wśród rządzących. Finansowanie sportu $\mathrm{z}$ budżetu państwa czy też jednostki samorządu terytorialnego może sprzyjać lobbingowi i wręczaniu prywatnych korzyści dla decydentów w zamian za korzystne dofinansowanie. Po pierwsze, działania takie są czynem karalnym, po drugie zaś ograniczają jakikolwiek wpływ społeczeństwa na alokację zasobów. Innym problemem we wspieraniu sportu $\mathrm{z}$ finansów publicznych jest asymetria informacji, czyli sytuacja, w której niektóre podmioty dysponują większym zasobem informacji niż druga strona. Zjawisko to jest jednym z przykładów niedoskonałości rynku, jednak ma ono również miejsce przy finansowaniu z budżetu państwa bądź też samorządu. Asymetria działa w dwie strony. Po pierwsze, więcej informacji na temat własnego budżetu posiadają władze i to one dzielą fundusze, co sprzyja wspomnianej już korupcji. Po drugie zaś, aby otrzymać dofinansowanie, należy 
spełniać różne oczekiwania, o których była już mowa w poprzednich punktach. Kluby czy też organizacje sportowe, które posiadają pełną wiedzę o własnej organizacji, mogą ukrywać niektóre fakty, a co za tym idzie, otrzymać dofinansowanie pomimo braku spełnienia wymogów. Ostatnim, głównym problemem jest nadzór nad wydatkowaniem przekazanych pieniędzy. Fundusze, które przeznaczane są organizacjom sportowym, najczęściej są funduszami celowymi, które określają, na co mogą być przeznaczone pieniądze. Problemem jest jednak ukrywanie prawdziwych wydatków i kosztochłonny system nadzoru nad wydatkami.

W październiku 2013 roku Najwyższa Izba Kontroli opublikowała raport dotyczący finansowania sportu przez samorządy w latach 2009-2011. Jak pokazano w poprzednim podrozdziale, to na gminach spoczywają szczegółowe zadania dotyczące wspierania sportu lokalnego. Ustawa o sporcie miała stworzyć spójne przepisy dotyczące sportu, a także dać większą swobodę w jego finansowaniu przez państwo i jednostki samorządu terytorialnego. Raport NIK przedstawia wyniki kontroli w sześciu gminach: Gdańsk, Poznań, Bydgoszcz, Lublin, Szczecin i dzielnica Warszawy - Śródmieście. Nakłady na sport są w nich ogromne - w ciągu 2,5 roku w gminach tych wydano ponad 1,6 mld złotych. W tej kwocie zawierają się pieniądze przeznaczone na utrzymywanie obiektów sportowych i działalność instytucji kultury fizycznej, a także na realizację zadań klubów sportowych. O konkretnych przykładach nieprawidłowości w utrzymaniu obiektów sportowych będzie mowa w dalszej części pracy. Natomiast warto przedstawić główne wnioski dotyczące nieprawidłowości, jakie formułuje NIK, a są to przede wszystkim (Datko, 2012, s. 16):

- niedozwolone przepisami wspieranie sportu,

- mechanizmy korupcjogenne,

- znaczne odstępstwa od postanowień przepisów i umów,

- bardzo niejasne zasady wspierania klubów, zlecania im zadań oraz rozliczania z nich,

- brak nadzoru nad przeznaczonymi na kluby pieniędzmi.

Ponad 91 mln złotych przeznaczono w tych latach na dotację klubów sportowych. O ile sport amatorski może, a nawet powinien być finansowany z budżetu samorządu, o tyle fundusze przeznaczane na sport wyczynowy podlegają innym zasadom, ponieważ można finansować go wyłącznie poprzez stypendia za osiągnięcia sportowe dla trenerów i zawodników. Inną sprawę stanowią kluby sportowe, w których miasta posiadają swoje udziały, ponieważ ich dofinansowanie traktowane jest jako inwestycja. $\mathrm{W}$ badanych gminach aż cztery z sześciu naruszyły przepisy dotyczące finansowania klubów sportowych. Fundusze, które zostały przekazane z nieprawidłowościami, to aż 22,5 mln złotych. Ponadto 95\% wszystkich dotacji na kluby sportowe przyznano w otwartych konkursach, $5 \%$ zaś na wnioski klubów. Ten proceder można byłoby uznać za pozytywny, gdyby nie fakt, że w ofertach brakowało danych wymaganych przepisami lub dane te były niezgodne ze stanem faktycznym. W samych ofertach również dochodziło do nieprawidłowości, gdyż zasady rozpatrywania ofert nie były 
takie same dla wszystkich klubów bądź oceniano pozytywnie wnioski, które miały widoczne braki. Głównym błędem gmin był również nadzór nad komisjami, które przyznawały fundusze, oraz nad klubami.

Innym zaniechaniem ze strony gmin był brak kontroli nad danymi, które dostarczały kluby lub organizatorzy wydarzeń sportowych. Kolejną sprawę stanowią udziały gmin w klubach sportowych, co zostało wspomniane wcześniej. Połowa badanych gmin, a mianowicie Szczecin, Lublin i Bydgoszcz, posiadała akcje klubów sportowych. Łącznie ulokowane w nich było $16 \mathrm{mln}$ złotych. Spółki sportowe przynosiły jednak olbrzymie straty. Jedynym pozytywnym aspektem wynikającym $z$ raportu NIK było finansowanie przez badane gminy pozalekcyjnego sportu szkolnego (Bruhn, 2003).

Drugim raportem, który dotyczy nieprawidłowości we wspieraniu sportu z pieniędzy publicznych, był raport NIK dotyczący modernizacji Stadionu Śląskiego w Chorzowie. Jako że przebudowa stadionu trwa już ponad 20 lat i kosztowała dotychczas ponad 600 mln złotych, Najwyższa Izba Kontroli postanowiła zbadać tę sprawę. W raporcie przedstawiono takie nieprawidłowości jak:

- nieprawidłowe działania urzędników związane z wyborem droższego i niesprawdzonego projektu zadaszenia trybun,

- odstąpienie od uzasadnionego projektu zadaszenia trybun,

- niejednolity sposób weryfikacji projektów,

- łamanie prawa dotyczącego zamówień publicznych.

Zarzuty NIK są bardzo poważne, dlatego postanowiono złożyć zawiadomienie do prokuratury o możliwości popełnienia przestępstwa. Środki przeznaczane na modernizację stadionu pochodzą głównie z budżetu województwa śląskiego. Wiele funduszy zostało jednak przeznaczonych na niepotrzebne i nierzetelne analizy, które miały podważyć wcześniej zatwierdzony zgodnie z przepisami projekt zadaszenia stadionu. Nowy projekt jest zdecydowanie droższy i jak pokazały działania praktyczne, znacznie gorszy. Ponadto nowego wykonawcę wybrano $\mathrm{z}$ wolnej ręki, a nie w trybie konkursowym, pomimo tego, że koszty nowego projektu były o $55 \mathrm{mln}$ wyższe niż u poprzedniego i zweryfikowanego wykonawcy. Główne nieprawidłowości to podejrzenie o niegospodarność oraz niebezpieczeństwo katastrofy budowlanej.

Dwa zaprezentowane raporty dotyczą wspierania sportu przez samorząd terytorialny. Ostatni prezentowany raport Najwyższej Izby Kontroli dotyczy wkładu państwa we wspieranie sportu wykwalifikowanego, co należy do ustawowych zadań państwa opisanych w poprzednim podrozdziale. Nieprawidłowości związane z tymi działaniami przedstawia raport NIK dotyczący Centralnego Ośrodku Sportu oraz ośrodków przygotowań olimpijskich. Wedle tego raportu ponad 50\% reprezentantów kraju w sportach olimpijskich i paraolimpijskich nie miało zapewnionych odpowiednich warunków do treningu w kraju, ze względu na braki w sprzęcie i obiektach sportowych. Dodatkowo COS nie posiada żadnej strategii rozwoju, pomimo tego, że jest jedynym w kraju specjalistycznym podmiotem szkolenia kadry narodowej i olimpijskiej. Centralny Ośrodek Sportu posiada swoje obiekty we Władysławowie, 
Szczyrku, Spale, Wałczu, Giżycku i Zakopanem. Najważniejsze nieprawidłowości, które ujawnił raport, dotyczyły:

- braków obiektów sportowych i sprzętu,

- słabego zarządzania istniejącymi obiektami,

- złego zarządzania finansami.

Jak pokazały różne przykłady, pomimo coraz bardziej udoskonalanych przepisów prawnych, m.in. powstania Ustawy o sporcie w 2010 roku, nadal istnieją liczne nieprawidłowości we wspieraniu sportu z budżetu jednostek samorządu terytorialnego i państwa. Oczywiście nie oznacza to, że tylko sponsoring prywatny jest rozwiązaniem pozbawionym wad. Jednak ze względu na specyfikę tej pracy postanowiono skupić się wyłącznie na sektorze publicznym. Duże nieprawidłowości wynikały przede wszystkim z podstawowych zaniedbań, takich jak analiza dostarczanych dokumentów czy też brak kontroli. Ponadto raporty wykazały braki w znajomości przepisów, ich błędną interpretację lub zwykłe zaniechania w ich stosowaniu. Jednym z wniosków jest fakt, że wiele wskazywało na pojawianie się zjawisk korupcyjnych w analizowanych przypadkach. Kolejny podrozdział zaprezentuje skalę finansów podmiotów sportowych w zglobalizowanym świecie (Stiglitz, 2013, s. 112).

\section{LITERATURA}

[1] Bandarzewski K., Komercjalizacja przedsiębiorstw państwowych, Kantor Wydawniczy ZAKAMYCZE, Kraków 2003.

[2] Baumol W.J., Oates W.E., The Theory of Environmental Policy, Prentice Hall, Engewood Clifs 1997.

[3] Beech J., Chadwick S., The Business of Sport Management, Pearson Education, Harlow 2004.

[4] Brunn M., Sponsoring: Systematische Planung und integrativer Einsatz, Gabler Verlag Wiesbaden 2003.

[5] Datкo M., Sponsoring - klucz nowoczesnego sukcesu, Placet, Warszawa 2012.

[6] PatrzaŁek L., Finanse samorzadu terytorialnego, wyd. AE, Wrocław 2004.

[7] Stiglitz J.E., Ekonomia sektora publicznego, PWN, Warszawa 2013. 
